\title{
WOMEN OF WILL FOR NATION BUILDING IN PRAMOEDYA'S THREE EARLY NOVELS
}

\author{
Novita Dewi \\ Sanata Dharma University \\ Indonesia
}

\begin{abstract}
Of great interest to Pramoedya's writing, which is largely neglected, is the presence of ordinary women as supporting characters. This paper discusses the depiction of strongwilled women who embody the desired character that the Indonesian nationalists in the 1950s sought to construct in Pramoedya's three early novels, i.e. Keluarga Gerilya [The Guerilla Family] (1950), Korupsi [Corruption] (1954), and Sekali Peristiwa di Banten Selatan [Once Upon A Time in South Banten] (1958). Written during the period when nationalism in the country began to crack, the three novels present minor but arresting female characters: these women are able to find their right place in society as to excel and sometimes surpass men. Indeed, it is the presence of the characters that gives power to the narrative - that of a nation in decline. Using Fredric Jameson's interpretation of politics and literature as theoretical departure, this paper examines the novels against the backdrop of Indonesian social history after the first decade of independence. It is revealed that the presence of these female characters is not only allegorical to the Indonesian political reality of the day, but it also harbors aspirations and ideal visions of what future Indonesian society should be like.
\end{abstract}

\section{Keywords}

Strong-willed characters, repressed unconscious, nation building

Neither my grandmother nor my mother is forgotten. The literal meaning of the Indonesian word for hero, pahlawan, is a person -not someone necessarily great, just a regular person- whose life benefits others. My grandmother and mother benefited me. They are my role models. They live in all the many strong women characters who people my writings. And they live in all the people who have ever had to fight to be themselves. ${ }^{1}$

\section{About the Author}

Having earned her Doctorate in Southeast Asian Studies from the National University of Singapore in 2005, Novita Dewi currently teaches at the Graduate Program in English Language Studies, Sanata Dharma University, Jogjakarta, Indonesia. She received 
the 2007ASIA Fellows Awards for conducting research on people theatre for peace and reconciliation in Sri Lanka. In 2009, she secured an ASF Collaborative Grant and completed a project Peace Education through Arts, Rhythm and Literature (PEARL) with Dr. Theodore Fernando, S. J. from the Open University of Sri Lanka. Her research interests include Postcolonial Literatures, Popular Culture, and Language Education. She can be reached atnovitadewi9@gmail.com. 
PRAMOEDYA ANANTA TOER'S PORTRAYAL OF FEMALE CHARACTERS in his works is known to be quite sympathetic and positive. Readers of Pramoedya are familiar with Nyai Ontosoroh and several other women entangled in the life of Minke, the hero in his Buru Quartet as often shown in most scholarships on this Indonesian author. Scholarly writing on the treatment and/or influence of women in his other works also abound. ${ }^{2}$

This paper attempts to look at the portraits of strong-willed women in Pramoedya's three early but under-studied novels, i.e. Keluarga Gerilya [The Guerilla Family] (1950), Korupsi [Corruption] (1954) and Sekali Peristiwa di Banten Selatan [Once Upon A Time in South Banten] (1958). These less examined or "nonsignature" works by the Maestro are purposefully chosen here to discuss further Pramoedya's portrayal of women as part of his nationalist agenda.

A number of excellent articles have mentioned Keluarga Gerilya ${ }^{3}$ and Sekali Peristiwa di Banten Selatan ${ }^{4}$ in passing while discussion on Korupsi is almost non-existent, despite the fact that this novel inspired the francophone writer Tahar Ben Jelloun's writing of L'homme Rompu, thanks to Denys Lombard's translation of Pram's novel into French (Sastriyani 34). Another noteworthy article is Pramoedya's own writing on the making of Perburuan and Keluarga Gerilya eloquently translated and footnoted by Benedict Anderson (1983). None of the important works above, however, specifically addresses the depiction of women in the novels, since attention has mostly been paid to Pramoedya's reflection on Indonesia's embittered national history and life experiences that inhabit a space in his writing. As such, this paper presents a comparison and contrast of the female (minor) characters in the three novels and the ways in which their accounts can be seen as alternative re-interpretations of the Indonesian politics of the day.

\section{Theoretical Concepts and Historical Context}

Unlike conventional Marxist approaches to literature, the American Marxist critic Fredric Jameson argues that literature is not only a reflection but also a refraction of society. As such, literary analysis reveals the manner in which ideological discourses are produced and present in the text. Drawing on earlier Marxist criticisms and Lacanian psychoanalysis, in his Political Unconsciousness: Narrative as a Socially Symbolic Act (1981) Jameson charts how literature represents the hidden reality of exploitation and oppression within the society. Whenever contradictions and social problems are repressed, works of literature usually emerge as one out of many forms of symbolic responses. He says the following about the importance of interpreting (ways of reading) what the text represses:

Kritika Kultura 20 (2013): -027

(C) Ateneo de Manila University

<http://kritikakultura.ateneo.net> 
Interpretation proper - what we have called "strong" rewriting, in distinction from the weak rewriting of ethical codes, which all in one way or another project various notions of the unity and the coherence of consciousness- always presupposes, if not a conception of the unconscious itself, then at least some mechanism of mystification or repression in terms of which it would make sense to seek a latent meaning behind a manifest one, or to rewrite the surface categories of a text in the stronger language of a more fundamental interpretive code. (6o)

Jameson reminds us further that authors, however, are not always aware whether or not their works provide answers to the sociopolitical problems in question. The reader's task is thus to unearth from the text, the author's worldview (read: political unconsciousness) as part of the collective awareness of the repressed society. In so doing, his proposition is to use a psychoanalytical hermeneutic to read the suppression present in the text.

Therefore, while it may be simpler to read Pramoedya's writing through, for example, the lens of socialist realism, given the author's covert and politically populist inclination, there is always room to interpret his seemingly "correct" reflection of reality by making use of the Jamesonian model of interpretation as this present paper attempts to do. As such, it is important to first examine the historical circumstances of Indonesian society at the time of writing that helps create the author's ideological milieu to which discussion we now turn.

The novels chosen for discussion were written when President Sukarno made propagation of nationalism an ongoing affair as a bulwark against the country's disintegration. By the 1950s, the nationalists including Pramoedya were concerned that the Indonesian spirit of unity and oneness began to wane with rebellions in Ambon, Sulawesi and Aceh, while in Java, in which Pramoedya lived mostly of his life, Islamic dissents caused a threat to the nation-state. This is a decade analytically outlined by, among others, Herbert Feith in his seminal work The Decline of Constitutional Democracy in Indonesia (1962) ${ }^{5}$. The repeated changes to and implementation of the state constitutions followed by the mushrooming of political groups with diversified outlooks indicated this instability. Sukarno's amalgamation of such varied visions as nationalism, religion, and communism was but a fantasy of a unified Indonesian culture. His Guided Democracy thus failed inevitably.

Aside from the country's task of nation-(re)building, economic development was another grave concern. Yet, these two national undertakings of the young Republic were both untenable, given the differing views of the political elite. For leaders like Sukarno, social and political progress was the number one pursuit. On the contrary, for the other bench of the policy makers represented by Hatta, economic

Kritika Kultura 20 (2013): -027 
development was all the more urgent a priority. Added to the conflicting economic plans as well as international affairs policy were incompetent management of natural resources and rampant corruption both in the Army and the cabinet that hastened the demise of the country. As appropriately noted by Feith, inflation that hit Indonesia helped exacerbate the moral degradation among civil servants as many of them became spendthrifts and corrupt bureaucrats during the Ali Sastroamidjoyo Cabinet of 1953 - 1955. This scenario became the subject of much criticism in the literature and popular culture of the day (Feith 406).

Indeed, this symptom of national breakdown at the turn of the decade was aptly read by literary scholars themselves believing that Indonesian expression of arts and culture of the period should be understood within this historical contour of Indonesian nationalism. The radical nationalists like Pramoedya resolved to believe that arts should exist for nation building, thus rejecting the right-wing view that arts should be free from any political endorsement (Foulcher 83-103). ${ }^{6}$ Having been plunged more deeply into literary war of this kind, Pramoedya subsequently aligned himself with the Institute of People's Culture [Lekra] which was supported by the Indonesian Communist Party by the turn of the decade. It should be noted here that while closely associated with the communists, this pro-people cultural organization attempted to transform the national culture in favor of the ordinary people's spirit, rather than a cultural devotion to communism. ${ }^{7}$

While Pramoedya's involvement in Lekra was condemned by his rivals leading to the novelist's life-time sufferings throughout the changing regime, his literary transformation in the 1950 os has drawn scholarly attention given its significance as claimed by a number of studies. Heinschke, for example, carefully maps out Pramoedya's literary journey throughout the period where he gradually detached himself from the Generation of 45 writers (identified themselves as Gelanggang writers) and finally sided with the Lekra authors. ${ }^{8}$ Pramoedya's change in political and, accordingly, literary worldviews, Heinschke argues, was a result of the novelist's difficulties in reconciling his ideas, ambitions, and personal goals with the political realities of the day to which Lekra could provide him a repository to materialize his literary ideas.

Meanwhile, Hong Liu claims that the People's Republic of China (PRC) and the literary politics of the country had left a profound impression on Pramoedya, influencing his intellectual, cultural, and political maturity. The novel Sekali Peristiwa di Banten Selatan, which was written soon after Pramoedya returned from China, Hong Liu points out, clearly exemplifies the novelist's political commitment with which his literary concepts develop from universal humanism to socialist realism (Liu 119-144).

Kritika Kultura 20 (2013): -027

(C) Ateneo de Manila University

<http://kritikakultura.ateneo.net> 
Bandel's recent commentary on the Indonesian translation of the much earlier study by Scherer From Culture to Politics: The Writings of Pramoedya A. Toer, 1950 - 1955 (1981) concludes that Pramoedya is a truly committed writer as proven by his persistence, courage, and openness to criticism in his continuous efforts to make literature function well in promoting equity, humanity, and ideology rather than simply aesthetics. ${ }^{9}$ Appreciating Scherer's finding on Pramoedya's intellectual progress towards a literature of his own, Bandel concurs that Pramoedya is consistent in his literary pursuits, contrary to another critic who tends to simplify the novelist's turning to the left as a mere solution to his financial problem. ${ }^{10}$

Suffice it to say at this point that the socio-political and cultural condition in 1950 Indonesia and its implication on Pramoedya's writing career cannot be ignored when examining the depth of the novelist's works during the period. It is against this particular historical context that his works (symbolic responses to the Real) can be better understood. Thus, with this brief snapshot of Indonesian cultural history and Fredric Jameson's concept of interpreting literature (history in narrative) being an unconscious political act, the three novels will now be examined. This paper argues that Pramoedya's attempt to speak about humanity when nationalism was dragged on its feet is effective by having the strong-willed female characters survive and fare better than their male counterparts.

\section{Précis of the Novels}

To ease the discussion, the plot summary of each novel will be given first. Keluarga Gerilya tells of a family torn-apart by war. It all begins with the arrest of Sa'aman (Aman) the undercover freedom fighter, leaving her widowed mother Amilah who doted on him and his under aged sisters Salamah (Amah), Patimah (Imah), Salami (Mimi), and youngest brother Hasan unsupported. The two other brothers, Tjanimin (Mimin) and Kartiman (Maman), are soldiers whom the family had earlier sent to serve the country. The family thus depends a lot not only on Aman's meager earnings as a becak driver, but also his wisdom as the eldest child in the family as well as father substitute. Paidjan, the father is a KNIL whom his pro-republic sons are compelled to kill which they feel remorseful for. A series of misfortunes befalls the family after Aman's arrest. The widow, as a result of these tragedies, lost her senses and disapproved of the eldest daughter Amah's going to work, for fear that the younger woman would meet many men at work. As a result, Amah's fiancée Darsono becomes the temporary provider for the family. One colonial government officer, Sergeant Kasdan, visits one day to see Amilah with news of Aman. The poor widow unthinkingly jumps to his offer of releasing Aman, on condition that it is her nubile daughter Amah who should come to pick him up; this was a ruse since Amah was sexually molested while Aman is still locked up in

Kritika Kultura 20 (2013): -027

(C) Ateneo de Manila University

<http://kritikakultura.ateneo.net> 
prison waiting for his execution. In the meantime, Amilah's second son Mimin has to kill his younger brother Maman in order not to disclose their hiding place. The enraged mother rushes back home and accidentally knocks on the oil lamp and soon sets ablaze their woven rattan house. The resolute woman runs all the way to the prison to see her beloved son. She is shortly shown to Aman's grave. She throws her frail body onto the fresh flowered mound and cries her heart out. Her cries know no time. In the afternoon, when people carry another corpse to bury in that cemetery, they find Amilah's dead body. The story closes with the rest of the siblings reading the last letter of Aman, while Darsono looks on, waiting to shoulder the family's burden.

More properly called a novella given its limited scope, length, and number of characters, Korupsi centers on Bakir, a government official in his 4.05 who is caught up in corruption scandals, perversely ignoring as he does the warning from his wife about the danger of what previously began with such petty indulgence as selling office supplies. The fundamental theme of the novel is that one person's actions have many effects on the any single action. Bakir first takes the bribe and commission from a big business. He then leaves his wife and four children for a young woman half his age, Sutidjah, using the money to live a lavish life in their new house in Bogor. Next, to conceal his crime and win people's sympathy, he attempts many different ploys such as conducting illiteracy eradication, giving Lebaran rice donations, giving dole-outs to victims of fire for people in the area. The misguided Bakir is also forced to join an adulterous gathering for the so-called muda kembali (rejuvenation) sessions involving government and military high officials who would meet in a house to be entertained by women (Ananta Toer, Korupsi 102). Participation in this group is necessary; otherwise his scandal would be exposed. Meanwhile, Bakir's relationship with Sutidjah grows colder. Riches have turned the once poor and innocent young woman into a surprisingly spendthrift and unfaithful wife. Bakir becomes gradually alienated from his staff in the office including Sirad, his formerly trusted employee. It is Sirad who then discloses his offense to the authority. The guilt-ridden Bakir cries with remorse when his first wife Mariam takes her children with her to the police station where he is detained and interrogated for his wrongdoings. Sirad one day visits him with startling news: not only is he fired from his office but Sutidjah is arrested for circulating fake money while vacationing in Bali with her friends. One Captain Muria has claimed himself the father of their daughter Rahmah. Regretfully Bakir recalls that he too has slept as many as seven times with Captain Muria's wife.

The last novel Sekali Peristiwa di Banten Selatan, in Pramoedya's own acknowledgement, borrows the traditional structure of drama: it was written to be performed (Ananta Toer, Sekali Peristiwa 7). The story paints the enduring picture of poor ordinary people in South Banten - victims of injustice and oppression from

Kritika Kultura 20 (2013): -027 
one powerful man named Juragan (literally Master or Lord) Musa who is closely linked to the village head (Pak Lurah). Musa occupies almost all plots of land in the area due to his inflated land rent scheme and thus leaves the farmers landless and destitute in their otherwise fertile soil. Worse still, he often makes his labors steal on his behalf some seeds of plants and criminalizes them afterward. Ranta and his wife Ireng are among the oppressed until one day they decide to break free from Musa's coercion by refusing the rich man's order to steal the rubber tree seed. Fighting ensued and Musa is kicked out of Ranta's house leaving behind his leather briefcase bag. It is this briefcase that revealed Musa's clandestine work as a member of the Darul Islam (DI). ${ }^{11}$ This rebellious Islamist group had terrorized Ranta's village with robbery, looting, killing, and many other destructive and violent conducts. It becomes clear why people found Musa's house and his family unharmed during the DI clash with the government army. Upon the discovery of his underground activity, Musa is quick to send his bogeymen to burn Ranta's house with the hope of killing the owner. But Ranta and his wife have escaped to town, mobilized the people to fight back the rebels, whose actions have impoverished the villagers, and reported Musa to the commander in charge. In a short time, Musa and his men including the village head who is also the DI secret member are under arrest. In support of Ranta and his wife, the neighbors in the village drive the radical group out. Ranta is then appointed the new village head, ready to build the life at South Banten anew. Meanwhile, Musa's wife, Nah, who has never known before about her husband's clandestine politics is raped and robbed on her way to her home town Sukabumi, ignoring as she does Ranta's advice to stay at home during the rough time. Her royal servant Rojali takes her back to meet Ranta and Ireng. Nah then decides to join them and participate in the village development program to teach basic reading and writing to the people.

\section{Portraits of Women in the Novels}

The discussion now turns to the ways in which a strong personality is a major trait of the women in the three novels and this characterization exerts ideological control over the nationalist model of the Indonesian people. It is therefore important to see how women figure in Pramoedya's novels to which Virginia Woolf 's maxim "For most of history, Anonymous was a woman" is only partly true. The female characters discussed here do not fall into stereotypes, be they mothers, wives, or daughters, given the novelist's belief in literature's relatedness with life where the portrayal of human condition and its extreme and emotion is often gender blind. "When it comes to gender," Pramoedya said when asked about feminist awakening, "I don't take sides" (GoGwilt 158).

Kritika Kultura 20 (2013): -027

(C) Ateneo de Manila University

<http://kritikakultura.ateneo.net> 
The female characters in these novels are comparable in that first, they all have a strong determination in life that they sometimes come across as idealists. Second, they are quick to change into hard-boiled realists when circumstances go against their principles. Their capacity to change in order to survive makes them repeatedly appear stronger than their male counterparts. It worth noting here that for the novelist himself, it is precisely the resolute, transformative characters as such that help support nation building. ${ }^{12}$ Read against Jameson's concept of the political unconscious, these novels are thus peopled by the desired, imagined Indonesian women at the age of Indonesia's waning nationalism and democracy. The characterization of these women in each novel will be discussed in turn.

\section{Uncovering the Unconscious in Keluarga Gerilya}

Incorporation of the author's story and that of his or her fictional character(s) is nothing new in narrative theory. ${ }^{13}$ But, it is this literary technique that allows Pramoedya to create his fresh fictional characters while continually expressing, in Jameson's term, his repressed ideas, personality, and political morality. The following quote from Pramoedya's 1995 Ramon Magsaysay Award Speech may help reveal the novelist's desire:

Each work of literature is necessarily the autobiography of its author, at a certain level and in a specific situation. Hence it is also an individual project - an individual contribution to the collective. It reflects the individual stance of the writer with regard to the reigning power, the prevalent cultural values, etc. The task of the writer is to evaluate and continue to reevaluate all aspects of life. Very often, the writer feels discontented, even cornered, and oppressed by the powers-that-be and the prevailing norm. The writer cries out, puts up a resistance, and might even rebel. ${ }^{14}$

The speech was written many decades later after he wrote Keluarga Gerilya; but the novelist harbored the same repressed political yearning when creating the indomitable Amilah - a wounded survivor of the Indonesian broken revolutionary movement symbolized by the incompetent men present in the text. It is worth pointing out that the presence of a strong mother amidst that of a weak father here is suggestive of Pramoedya's own disappointment with his father and admiration for both his grandmother and mother.

When we first meet Amilah in the novel, she is a difficult neighbor to live with: she is loud, hot tempered, impolite, confronting everyone including her children in order to impose her ideals. Having learned from her bitter and sweet experiences in the past with men, Amilah holds firmly to her principle of discouraging her daughter(s) from forming casual, easy relationships with men. For instance, she

Kritika Kultura 20 (2013): -027

(C) Ateneo de Manila University

<http://kritikakultura.ateneo.net> 
forbids Amah to find work where men are wont to harass women. Amilah's past romantic adventure and disturbing sexual history, the novelist tells us, has earned her a nickname "buaya tangsi" or, literally, crocodile of the military barrack (Ananta Toer, Keluarga Gerilja 7). At least three different army men posted in different places have fathered her seven children. The fact that these men all disappear from her life leaving the family poverty-stricken made Amilah guilty of her exploits in the past. "Why did not I learn to find work when I was young," the once good-looking woman says regretfully, "Why did I then keep thinking that there was no pleasant living outside the barrack?" $(K G, 11)$. Now that she is ageing, she faces the truth that "old woman has no value in the barrack", hence she condemns herself saying "this old age is indeed wicked - age has no currency in gaining the pleasure of the world" (KG 11). It is clear here that Amilah blames no one but herself for the present condition. She, therefore, does not want to repeat the same mistake to happen to her daughter in the future. Allusion to the body as Mother Country is mentioned here - a country made ugly by fading nationalism, conflicts, and disintegration.

Amilah is thus a hard-boiled realist like any female characters in the other two novels discussed later. She makes an interesting character for analysis because of her malleability, i.e. at one point she looks fierce but remains sane about getting what she wants most, but at other times, at the peak of her desperation, she appears lifeless. With the presence of shifting conflicts such as a dwindling family income following Aman's arrest and the desperate wait for her son's return, Amilah becomes frustrated. But given her undying hope to see Aman, she recovers her sense of purpose, even treading the tricky request of Sergeant Kasdan to use her daughter.

Later still, upon knowing that she is cheated by the sly sergeant, the angry mother retaliates to get even. When she reads about Aman's execution in the newspaper, Amilah storms into the prison to demand justice. It seems that there is nothing beyond the reach of determination for a realist like Amilah who is swift to act and react in pursuit of her goal. When eventually she learns about Aman's death, no one could stop the untiring woman from retrieving the dead body, causing troubles with the soldiers and prison director who then yield to her request.

Here, psychologists would probably find it easier to talk about the shamelessness in Amilah's life: her unsatisfactory marriage life, the pressing economic condition, her unmet emotional needs, loneliness, and the list can continue. But, using the Jamesonian lens of author's repression, this novel begs to be read differently. Amilah symbolizes the forced collapse of the country which she seeks to rebuild at all costs. At the expense of her own breakdown, Amilah wants her family to reunite because it is worth saving, hence the title of the novel.

Kritika Kultura 20 (2013): -027

(C) Ateneo de Manila University

<http://kritikakultura.ateneo.net> 
Similar to Amilah, her second daughter Patimah is another strong female character in the novel that bears striking similarities with Pramoedya's mother (an ideal person culled unconsciously) in that they are both intelligent and autonomous. Her presence in the novel merits some mention in this present discussion. Named to sound like the novelist's grandmother Satima, Patimah is characterized to resemble Saidah, the mother of Pramoedya - an independent, educated woman who pushed her eight children to excel in school. Pramoedya recalled that the children were never allowed to ask for something undeservedly even if it was a school notebook. ${ }^{15}$

The novelist allows the reader to see the characterization of Patimah throughout the narrative by her unswerving actions as well as favorable statements made by other characters on her. For instance, Patimah will be a "woman warrior", her sister claimed. Not only is she "smart and quick thinking", but is also in possession of "good character and great humanity" (KG 13). Dubbed by Aman in his last letter sent before his death sentence as "the smartest sister" and his "only hope for the family", this 17-year-old is advised to continue her study while maintaining her "budi" [good character] to succeed in life (KG 190). "You are a woman!" Aman writes to Patimah, "But there is no different between men and women in their pursuits of aspirations" (KG 191). It is easy to uncover the author's hidden message for nation building here.

We are still led to see the girl's autonomy in several occasions. Patimah volunteers to work in place of her elder sister. Next, despite her young age, her maturity is shown when she is discussing the struggle and value of the revolution with Darsono. She accepts with no difficulty her will-be-brother-in-law's theory that people who fight for revolutionary causes "prepared heaven for millions of his country people", better and more honorable than people who say prayer day after day preparing solely for a heaven of their own (KG 123). Thus, she adamantly refuses any help from Karel van Keerling, the prison director who approaches the siblings to see if he can help to obtain pardon for Aman, to which Patimah say "How disgraceful it is to plead to a person who is about to kill him." The Eurasian officer is herein described as dumbfounded "gazing at Patimah, admiring her eyes" and saying afterward "This is the first time I have ever heard such a statement" (KG 180).

Whether intended or not, the presence of the women in the text appears more dignified than that of men. But one can also look at the intertextuality between the imagined actors with the characters in Pramoedya's other books as well as the books he possibly used as reference, to effect a reconstruction of the author's ideology. Hasan the youngest in Keluarga Gerilya, for instance, is the curious little boy Ulysses in William Saroyan's Human Comedy (1943). This character is also alive in his short story "Blora": Tjuk is the talkative brother whom the narrator kills

Kritika Kultura 20 (2013): -027 
upon the commander brother's order. To follow Jameson, no attempt should be made to draw a parallel with Pramoedya's own youngest brother in this particular short story, ${ }^{16}$ since it is precisely the unpalatable, tragic ending of the narrative that represents the novelist's political unconscious.

To return to Amilah's family in the novel, the strong family bond, mutual concern, understanding, and kindness, while Saroyanesque, displays an autobiographical resonance. Here, the fact that this novel exhibits a degree of intertextuality too good to ignore further highlights the novelist's repressed wish of what the Indonesians society should be like. Then, to achieve this end, Pramoedya lives in the thoughts and actions of several characters that serve as his surrogate within the narrative.

First, his persona appears most clearly in Aman the eldest brother, especially in his role as main source of income and advisor to his siblings. But Aman is actually modeled on the real character Wahab (Ananta Toer, "Perburuan 1950 and Keluarga Gerilya 1950 25-48). This characterization mirrors Pramoedya's own dilemma of becoming a soldier who was once entrusted to place an able fighter like Wahab properly. The novelist admitted that he did not do justice to Wahab for not having given the falling hero the glory he deserved through the character of Aman ("Perburuan and Keluarga" 43).

Second, the manner of the fighter's burial in fiction is yet another source of regret, for in the story, the repentant jailer Karel van Keerling is the one who organized Aman's funeral, while in reality, it was Wahab's poor mother who had to save some money to take back Wahab's body to be buried properly. No sooner had Pramoedya sent the Keluarga Gerilya manuscript for publication than knowledge of this moving family incident reached him. This account alone helps explain the novelist's admiration toward the strong women from which he drew inspiration for his imagined character in representing his beloved country, as the second novel under discussion will show below.

\section{Principle Holders in Korupsi}

As different from Amilah, the heroine in Korupsi is gentle and caring. But the two women are similar in terms of upholding their principles despite the family breakdown, the irresponsibility of male bread-winners, government officials' fraud - all can be read here as a national allegory. Readers associate Mariam's character, near the end of this 154-page-novel, with the figure of the Virgin Mary, given her loyalty and capacity to sustain life for her family in thorny time. ${ }^{17}$ Her name suggests hope, for it is the name recalled during Bakir's days of darkness as he muses about her: "So humble a heart, so honorable a soul" (K 148). A determined and loving

Kritika Kultura 20 (2013): -027

(C) Ateneo de Manila University

<http://kritikakultura.ateneo.net> 
woman, Mariam emerges as the family's center of strength over the course of the novel as her husband has gradually become irresponsible as a father and provider. Time and again, Mariam displayed an unusual capacity to keep herself and the family together - at the face of many problems from being assaulted, abandoned, and betrayed by Bakir, raising children all by herself, to her husband's being charged with corruption.

Integrity was Mariam's uncompromising principle in life. She firmly believes that dishonesty comes with a cost named fear. When she finds out that her husband is about to commit an act of corruption, she reproaches him thus: "Should your fortress of honesty be infiltrated for the first time, you'll succumb. You'll continue to succumb to your insatiable lusts and you no longer own your fortress. Only forces outside yourself can help you" $(K 47)$. Mariam continues to warn her husband with the evil consequences of corruption: leaving or being left by friends and then gaining acquaintanceship with his new friends only to find they are just as bad and guilt-ridden. She next likens him with a "beast of prey" for he had to "run and keep running until he dropped dead" chased by his own torment $\left(\begin{array}{l}K \\ 48\end{array}\right)$.

It is clear here that the novelist's loathsome description of a corruptor is made clearer through Mariam's utter disagreement with her husband's behavior. Here, Bakir's perverse actions and suppressed guilt are effectively presented in the story by having the male protagonist "see" the presence of his wife in his mind. Thus, by creating a credulous character like Bakir in this satirical novel, Pramoedya seemed to borrow woman's conscience as an extension of his own disgust with corruption - a social predicament he hated to witness in Indonesia for the rest of his life. ${ }^{18}$ Read in today's context, Bakir, coincidentally or otherwise, is a name strongly reminiscent of (Aburizal) Bakrie, businesman and Chairman of the Golkar (Indonesian biggest political party) who will soon announce his candidancy in the next 2014 Presidential election despite his shabby treatment of the devasted life of the mud flow victims in Sidoarjo caused by the negligence of Bakrie's family company - a case left unresolved since 2006.

It is thus not an exaggeration to say that Pramoedya's attack on bureaucrats, hypocrisy, and corruption still resonate strongly even today, thanks partly to the women's focalization in his novels. He makes use of the female characters conveniently to function as an eye opener for men whose credulity he himself despised. At this particular juncture, unlike "traditional" Marxist reading, the Jamesonian concept may help reveal that Pramoedya's works are far from pamphleteering. The novelist has his own way to persuade readers about such issues as patriotism, audacity, moral leadership, equity, freedom, and many others. To Idrus's account, disputed by Ben Anderson, on Pramoedya's writing ability that

Kritika Kultura 20 (2013): -027 
"what he produces are simply dongeng [tales]", ${ }^{19}$ we might as well quip: "He is not just a story-teller."

\section{Hard-boiled Realists in Sekali Peristiwa di Banten Selatan}

Ireng and Nah are, respectively, the wives of Ranta and Juragan Musa in the novel often picked up specifically either for marking Pramoedya's political change, ${ }^{20}$ or for the novel's lack of literariness (Liu, "Pramoedya Ananta Toer in China" 138). Although the two women in Sekali Peristiwa di Banten Selatan are depicted through their feminine ideals of honesty and loyalty, their role as "enablers" for their husbands' power as decision makers is hard to ignore. Both Ireng and Nah try to live up to their firmly held principle of becoming active supporters for justice.

Ireng, for example, is quick to take action by fighting back once she knows from her husband about Juragan Musa's cruelty towards the farmers. Here, Pramoedya characterizes her as being more "manly" than her husband Ranta who often comes across as placid and patient. While Ranta's depiction is that of a calm person, the novelist often uses some vigorous word choices for Ireng like "menyambar" [thundering], "geram" [infuriated], to say nothing of her use of name-calling as "Sibuaya" [crocodile] for the mean Musa. The contrast can be seen in the dialogue in this drama-like novel which was reportedly performed in Medan in the late 1950's ${ }^{21}$ as follows:

Be quiet, Ireng, Be quiet.

If I were a man, Pak, I had broken his neck for a long time. He forced you, who have been to this day so good to him, to become a thief!

Be quiet Ireng.

Quiet? You are my man, not his man. What to do when bad things happen?

Ranta got up from his seat, holding Ireng's hands and gently spoke to her word by word, clearly, softly, and lovingly: Time will come, Ireng, when we shall have a good and happy life. It will. (SPBS 19)

Like Ireng, the wife of Musa, Nah, is supportive and loyal to her husband until she finds out about his misdemeanor. That Nah is a woman who upholds her principle of justice is clear when she says this: "If he [Musa] is a DI member, surely he should be arrested" (SPBS 80). Yet, at the same time, she remains a faithful partner in difficult time as shown from the following statement when pressed further about her husband's involvement:

Kritika Kultura 20 (2013): -027

(C) Ateneo de Manila University

<http://kritikakultura.ateneo.net> 
Had I known long before, perhaps I could have stopped him from so doing. I think, none of the decent people would not condemn DI. But do not forget Pak Lurah, a wife is obligated to defend and assist her husband. (SPBS 81)

Here, the persona of Nah is also similar to Amilah in Keluarga Gerilya in her innate ability to deliver a prompt reaction. She is able to recognize the reality upon which she then takes further actions. First, despite her disagreement with the rebellion, she is adamant about defending her husband in the fulfillment of her duty as a wife. As such, she chooses to leave the village to return to her hometown against all odds. But her devotion evaporates. Becoming a victim of sexual assault by the rebels is but a reality check for her, hence the quick decision to support instead the nationalist struggle. This wife of Musa is able to accept the fact that her idealism of becoming a devoted wife hardly fits in with the context of ordinary reality, i.e. the pressing call for freedom from oppression and stupidity. Probably named after Maemunah Thamrin, Pramoedya's second wife, Nah is also quick to realize that with her ability, she could contribute a lot more by devoting herself to teaching her fellow women. Women's involvement in this literacy program further suggests the nation's belief in the equity for all in pursuit of what Salleh Yaapar called "Great Malay Nation". ${ }^{22}$ Near the end of the story, we are told that Nah is happy with her choice to stay in order to do the work she has to do.

It would seem here that Pramoedya, again, projects the qualities of his grandmother and mother in Ireng and $\mathrm{Nah}$ in this novel, and the wise and autonomous Mariam in Korupsi mentioned above for these women's refusal to beg and trouble anyone. We are given the portraits of women who are able to think, feel, and act in accordance to their own discernment. They are not easily influenced but persistently maintained such principles as independence, integrity, and justice. Women can thus be she-roes in the novelist's hands.

But Pramoedya's female hero par excellence whom he often recycled for his female characters is Kartini whose concern for education is a template for Nah with her literacy program. In his two-volume biography Panggil Aku Kartini Sadja [Just Call me Kartini] (1962), Pramoedya criticizes the way in which Kartini is usually constructed as a mythical figure, hence preventing us from appreciating her fully as a human being. ${ }^{23}$ As a personal note, Pramoedya reiterated his admiration of Kartini and lamented his people's lack of knowledge of their own history while challenging me to name other female heroes of Indonesia. ${ }^{24}$ It can be argued here that it is real figures like Kartini and Pramoedya's own maternal parents that are used invariably as a pattern for his female characters: individuals capable of becoming instigators for society at large - a leader.

Kritika Kultura 20 (2013): -027

(C) Ateneo de Manila University

<http://kritikakultura.ateneo.net> 
To return to the novel discussed, it is clear that women are cast as realistic characters to adapt accordingly when circumstances so required. Like Mariam in Koruspsi, Ireng, for example, knows that her husband is weak. Just as Ranta is too careful in revolting against the oppression, so is Bakir in his inner revolution to combat corruption. In this eventuality, each of the women takes an active role by encouraging their respective partners to take action. Ireng kept pushing Ranta to challenge Musa, while Mariam has convinced Bakir to battle his enemy within. Both of them sensibly brave the consequences of their choice: Ireng is ready to endure the pain of Musa's vengeance, while Mariam takes on the hardship of becoming a single parent. Here, the suffering women are present in the novels to uncover the political unconscious, i.e. exploitation and oppression by men (read: government). These simple ordinary women become saviors by the end of each story: for the family (Mariam) and for the larger community (Ireng and Nah).

In sum, the portrayal of helpless and submissive wives of the more dominating spouses is not found in Keluarga Gerilya, Korupsi, and Sekali Peristiwa di Banten Selatan. The depiction of the female characters as women of will is well maintained all the way through the novels as shown in their various abilities to exert influence on others, especially their husbands. This is not to say, however, that these women are flawless. But compared to their husbands, they are more capable of locating their own state and taking advantage of the given circumstances in order to survive. It is clear by now that women in Keluarga Gerilya, Korupsi, and Sekali Peristiwa di Banten Selatan are all partners of the less socially adept men. In particular, the usually forgotten roles of women in the nation's history are clearly pronounced in the third novel, as each of the women help alter the course of, in this case, the history of Islamist rebellion in Indonesia. All resilient female characters here can thus be seen as perfect templates for women in Pramoedya's later works - hence recycled in the unnamed girl in Gadis Pantai, Larasati in the novel of the same name, Dedes and Umang in Arok Dedes, to mention just a few.

\section{Conclusion}

The women in Keluarga Gerilya, Korupsi, and Sekali Peristiwa di Banten Selatan are, by no means, key characters, yet they are so constructed to find their proper place in life and do well in their own ways as to outshine men in either personal or national struggle. Therefore, the effects of the heroines' actions and reactions on the all male protagonists are worthy of consideration. Indeed, it is the presence of the characters as different as a little weird but unwavering widow, morally upright mother and wife, as well as courageous and patriotic women that give each story its power: a formula given by the novelist for character building and what a nation should be like. As such, just as Fredric Jameson's three novelists, Scott, Balzac,

Kritika Kultura 20 (2013): -027

(C) Ateneo de Manila University

<http://kritikakultura.ateneo.net> 
Dreiser, in The Political Unconscious, reveal the political desire of their respective society at each given era, so does Pramoedya reanimate the Indonesian nationalist political movements at the face of the country's impending disintegration in the 1950 s through his narratives on strong-willed women. In the three novels discussed, readers are allowed to see the height of Pramoedya's nationalist (as well as moral) platform - he champions patriotism, harmony, and equity, while fighting treachery, disintegration, and greed in all forms.

In conclusion, Pramoedya's accounts on women, apparently, never fail to fascinate readers with their varied, sometimes contradictory, characteristics of bravery weakness, vengeance, forgiveness, honesty, deceit, and so on. The female characters make every text here interesting as they all have the potential to reveal the often blurred boundaries of joys and sorrows in the harsh realities of life in a young independent country like Indonesia. The various ways in which different women are herein portrayed disclose how such a thing as entrapment of power as in war, corruption, rebellion is destructive, to be belatedly realized when men and women begin to contemplate their own failings. The stories of these ordinary people here help inspire people of the entire nation. Therefore, they are all heroes, whose life benefits others, just like the novelist's own definition of the word as quoted in the beginning of this article. 


\section{Works Cited}

Bandel, Katrin. "Perempuan Pesisir dalam Novel Gadis Pantai dan Jamangilak Tak Pernah Menangis" [Coastal Women in Gadis Pantai and Jamangilak Tak Pernah Menangis], boemipoetra (November-December 2008): 3 - 4 .

Bandel, Katrin. Book Launch Address. KUNCI Cultural Studies Center, Yogyakarta, 28 January 2012.

Clayton, Jay and Eric Rothstein. "Figures in the Corpus: Theories of Influence and Intertextuality" In Influence and Intertextuality in Literary History. Madison: The University of Wisconsin Press, 1991. 3 - 36.

Dewi, Novita. "Every Book Has a Voice: A Postcolonial Reading of Gadis Pantai and Larasati" Asian Englishes: An International Journal of the Sociolinguistics of English in Asia/Pacific 10. 2 (Winter 2007): 82 - 91.

Feith, Herbert. The Decline of Constitutional Democracy in Indonesia. Ithaca, N. Y.: Cornell University Press, 1962.

Foulcher, Keith. "The Early Fiction of Pramoedya Ananta Toer, 1946-1949" In Text/ Politics in Island Southeast Asia. Ed. D. M. Roskies. Athens, Ohio: Ohio University Centre for International Studies, 1993. 191-220.

Foulcher, Keith. "Literature, Cultural Politics, and the Indonesian Revolution" In Text/ Politics in Island Southeast Asia. Ed. D. M. Roskies. Athens: Ohio University Centre for International Studies, 1993. 221-55.

Foulcher, Keith. "Politics and Literature in Indonesia: The View from the Left" Southeast Asian Journal of Social Science 15. 1 (1987): 83-103.

Foulcher, Keith. Social Commitment in Literature and the Arts, The Indonesian "Institute of People's Culture" 1950-1965. Clayton, Victoria: Centre of Southeast Asian Studies, Monash University, 1986.

GoGwlit, Christ. "Pramoedya's Fiction and History: An Interview with Indonesian Novelist Pramoedya Ananta Toer" The Yale Journal of Criticism 9. 1 (1996): 158.

Hartley. Barbara. "Blora Revisited" Indonesia 30 (October 1980): 1 - 16.

Heinschke, Martina. "Between Gelanggang and Lekra: Pramoedya's Developing Literary Concepts" Indonesia 61 (April 1996): 145 - 170.

Kritika Kultura 20 (2013): -027

(c) Ateneo de Manila University

<http://kritikakultura.ateneo.net> 
Jameson, Fredric. The Political Unconscious: Narrative as a Socially Symbolic Act. Ithaca, N.Y.: Cornell University Press, 1981.

Hellwig, Tineke. In the Shadow of Change: Images of Women in Indonesian Literature. Berkeley: Center for South and Southeast Asian Studies University of California at Berkeley, 1994.

Hong Liu. "Pramoedya Ananta Toer and China: The Transformation of a Cultural Intellectual" Indonesia 61 (April 1996): 119 - 144.

Sastriyani, Siti Hariti. Sastra Terjemahan Perancis - Indonesia [Translated French Literature to Indonesian]. Yogyakarta: Gadjah Mada University Press, 2011.

Taylor, Jean Gelman. Indonesia: Peoples and Histories. New Haven: Yale University Press, 2003.

Temby, Quinton. "Imagining an Islamic State in Indonesia: From Darul Islam to Jemah Islamiyah" Indonesia (April 2010): $1-36$.

Toer, Pramoedya Ananta. Keluarga Gerilja. Djakarta: P. T. Pembangunan, 1955.

Toer, Pramoedya Ananta, Panggil Aku Kartini Sadja, Volume 1. Bukittingi, Jakarta: N. V. Nusantara, 1962.

Toer, Pramoedya Ananta. Korupsi. Jakarta: N. V. Nusantara, 1964.

Toer, Pramoedya Ananta (B, Anderson, Trans.), "Perburuan 1950 and Keluarga Gerilya 1950" Indonesia 36 (October 1983): $25-48$.

Toer, Pramoedya Ananta (Marianne Katoppo., Trans.) "Literature, Censorship and the State: How Dangerous are Stories" 2o November 2011 (http://www.antenna. nl/ fwillems/eng/poet/pram/magspee.html)

Toer, Pramoedya Ananta. Tales From Djakarta: Caricatures of Circumstances and their Human Beings. Translation of Tjerita dari Djakarta [1963] by the Nusantara Translation Group. Jakarta: Equinox Publishing Asia, 2000.

Toer, Pramoedya Ananta. Sekali Peristiwa di Banten Selatan. Jakarta: Lentera Dipantara, 2006. 
Toer, Koesalah Soebagyo. Pramoedya Ananta Toer dari Dekat Sekali: Catatan Pribadi Koesalah Soebagyo Toer. Jakarta: Kepustakaan Populer Gramedia, 2006.

"What They Did with Their Lives", TIME, April 29, 2002. 46 - 47.

Yaapar, Salleh. “Tetralogi Buru, Perjuangan Bahasa Melayu dan Gagasan Bangsa Melayu Besar" [Buru Tetralogy, Malay Language's Struggle and Ideas of Great Malay Nation], A Paper delivered at the Third RAFIL Conference, Departement of Malay Studies, National University Singapore, 11 - 13 November 2011.

\section{Notes}

1. What They Did with Their Lives" TIME, 29 April 2002: 47.

2. See for instance, T. Hellwig, In the Shadow of Change: Images of Women in Indonesian Literature (Berkeley: Center for South and Southeast Asian Studies University of California at Berkeley, 1994); N. Dewi, "Every Book Has a Voice: A Postcolonial Reading of Gadis Pantai and Larasati" Asian Englishes: An International Journal of the Sociolinguistics of English in Asia/Pacific 10. 2 (Winter 2007): 82 - 91; and K. Bandel, "Perempuan Pesisir dalam Novel Gadis Pantai dan Jamangilak Tak Pernah Menangis" [Coastal Women in Gadis Pantai and Jamangilak Tak Pernah Menangis], boemipoetra (November-December 2008): $3-4$.

3. See K. Foulcher, Keith. "The Early Fiction of Pramoedya Ananta Toer, 19461949" in Text/Politics in Island Southeast Asia. (Ed. Roskies. Athens, Ohio: Ohio University Centre for International Studies, 1993)191-220 and M. Heinschke, "Between Gelanggang and Lekra: Pramoedya's Developing Literary Concepts" Indonesia 61 (April 1996): 145 - 170.

4. See M. Heinschke, "Between Gelanggang and Lekra: Pramoedya's Developing Literary Concepts" Indonesia 61 (April 1996): 145 - 170 and Hong Liu, "Pramoedya Ananta Toer and China: The Transformation of a Cultural Intellectual" Indonesia 61 (April 1996): 119 - 144.

5. This malfunctioned democracy, as noted by Taylor, was given various names in political science and history such as the just mentioned "decline" by Herb Feith or Harry Benda's "aberration". See Jean Gelman Taylor, Indonesia: Peoples and Histories (New Haven: Yale University Press, 2003) 298.

6. K. Foulcher, "Politics and Literature in Indonesia: The View from the Left" Southeast Asian Journal of Social Science 15. 1 (1987): 83-103. Further discussion on this political divide, see also his Social Commitment in Literature and the Arts, The Indonesian "Institute of People's Culture" 1950-1965 (Clayton, Victoria: Centre of Southeast Asian Studies, Monash).

7. It becomes apparent here that the Indonesian literary preferences, the role of the dominant class, and the ideological control on the nation's cultural production of the time fit neatly with Fredric Jameson's three-world system of interpretations. 
8. See M. Heinschke, "Between Gelanggang and Lekra: Pramoedya's Developing Literary Concepts” Indonesia 61 (April 1996): 145 - 170.

9. K. Bandel, address, Book Launch, KUNCI Cultural Studies Center, Yogyakarta, 28 January 2012.

10. The critic in question is the well known writer Ajip Rosidi who provides Introduction to the translated version of Scherer's book hereby entitled Pramoedya Ananta Toer: Luruh dalam Ideologi (Jakarta: Komunitas Bambu, 2012).

11. Proclaimed in 1949 by Kartosoewiryo, the Islamic State of Indonesia consists of fanatical community whose underground movement was suppressed by Sukarno. Recent scholar claims that the movement has clandestinely survived, and that to date, the Southeast Asian based Jemaah Islamiyah groups who have continued their terrorist activities are the metamorphoses. See Quinton Temby's "Imagining an Islamic State in Indonesia: From Darul Islam to Jemah Islamiyah" Indonesia (April 2010): $1-36$.

12. Pramoedya used the words "membentuk individu" [molding an individually good character] when asked about his best hope for readers of his works. My interview with Pramoedya in Bojong Gede, 18 September 2002.

13. See, for example, the work of Jay Clayton and Eric Rothstein "Figures in the Corpus: Theories of Influence and Intertextuality" in their edited book Influence and Intertextuality in Literary History (Madison: The University of Wisconsin Press, 1991) $3-36$.

14. Pramoedya Ananta Toer, "Literature, Censorship and the State: How Dangerous are Stories", translated by Marianne Katoppo.

15. What They Did with Their Lives", 47.

16. Pramoedya's sister is reportedly unhappy with the grandmother character in the story who is depicted as a beggar. See Barbara Hartley's "Blora Revisited" Indonesia 30 (October 1980): 1 - 16.

17. I hardly suggest herein that Pramoedya made a name association with that of Virgin Mary, for he was quite relaxed about name-giving. In an interview, for instance, he dismissed the importance of a name for name is merely appearance to him. See Chris GoGwlit, "Pramoedya's Fiction and History", 147 - 164.

18. In 2004, when asked about his opinion on President Susilo Bambang Yudoyono's election promises to crackdown on widespread corruption after the first 100 days of his new government, Pramoedya was reportedly laughing his head off, saying that in Indonesian consumerist society, corruption dies hard. See Pramoedya Ananta Toer dari Dekat Sekali: Catatan Pribadi Koesalah Soebagyo Toer (Jakarta: KPG, 2006) 236.

19. Quoted from Ben Anderson's Introduction to Pramoedya's Tales From Djakarta (Tjerita dari Djakarta[1963]) translated by the Nusantara Translation Group (Jakarta: Equinox Publishing Asia, 200o) xi.

20. See M. Heinschke, "Between Gelanggang and Lekra", 165; and Hong Liu, "Pramoedya Ananta Toer and China", 138.

21. See Hong Liu, "Pramoedya Ananta Toer and China", 138n.8o.

Kritika Kultura 20 (2013): -027 
22. Yaapar contends that Pramoedya's postcolonial resistance is shown effectively through the persona of Minke in the Buru Tetralogy in his use of the Malay language, hence the novelist's own idealism of one language - one nation. See his "Tetralogi Buru, Perjuangan Bahasa Melayu dan Gagasan Bangsa MelayuBesar" [Buru Tetralogy, Malay Language's Struggle and Ideas of Great Malay Nation], Paper delivered at the Third RAFIL Conference, Departement of Malay Studies, National University Singapore, 11 - 13 November 2011.

23. Pramoedya Ananta Toer. Panggil Aku Kartini Sadja, Volume 1. (Bukittingi, Jakarta: N. V. Nusantara, 1962) x.

24. Pramoedya was amused when my companion, a history teacher, mentioned Rohana Kudus -a name the novelist had forgotten until then- as I recalled with difficulty more known names like Dewi Sartika, Cut Nyak Dien, and Martha Tiahahu. These non-Javanese female heroes, Pramoedya maintained, were never reduced to myths, unlike Kartini. My interview with Pramoedya in Bojong Gede, 18 September 2002.

Kritika Kultura 20 (2013): -027

(c) Ateneo de Manila University

<http://kritikakultura.ateneo.net> 